\title{
ASSESSING SOIL EROSION AFTER FIRE AND REHABILITATION TREATMENTS IN NW SPAIN: PERFORMANCE OF RUSLE AND REVISED MORGAN-MORGAN-FINNEY MODELS
}

\author{
C. FERNÁNDEZ ${ }^{1 *}$, J. A. VEGA ${ }^{1}$ AND D. C. S. VIEIRA ${ }^{2}$ \\ ${ }^{1}$ Centro de Investigación Forestal de Lourizán, Consellería do Medio Rural, Xunta de Galicia, PO Box 127, 36080 Pontevedra, Spain \\ ${ }^{2}$ Centro de Estudos do Ambiente e do Mar (CESAM), Universidade de Aveiro, 3810-193 Aveiro, Portugal \\ Received 11 August 2009; Revised 3 November 2009; Accepted 23 November 2009
}

\begin{abstract}
Although the Revised Universal Soil Loss Equation (RUSLE) and the revised Morgan-Morgan-Finney (MMF) are well-known models, not much information is available as regards their suitability in predicting post-fire soil erosion in forest soils. The lack of information is even more pronounced as regards post-fire rehabilitation treatments.

This study compared the soil erosion predicted by the RUSLE and the revised MMF model with the observed values of soil losses, for the first year following fire, in two burned areas in NW of Spain with different levels of fire severity. The applicability of both models to estimate soil losses after three rehabilitation treatments applied in a severely burned area was also tested.

The MMF model presented reasonable accuracy in the predictions while the RUSLE clearly overestimated the observed erosion rates. When the R and C factors obtained by the RUSLE formulation were multiplied by 0.7 and 0.865 , respectively, the efficiency of the equation improved.

Both models showed their capability to be used as operational tools to help managers to determine action priorities in areas of high risk of degradation by erosion after fire. Copyright (C) 2010 John Wiley \& Sons, Ltd.
\end{abstract}

KEY WORDS: soil erosion; RUSLE; MMF; wildfire; fire severity; rehabilitation treatments; Spain

\section{INTRODUCTION}

Post-fire erosion is a major concern to society because of the potential effects on soil and water resources. Increases in soil erosion rates are frequently observed following wildfire (e.g. Megahan and Molitor, 1975; Campbell et al., 1977; San Roque et al., 1985; Shakesby et al., 1993; Scott et al., 1998; Robichaud and Brown, 2000; Johansen et al., 2001; Martin and Moody, 2001; Meyer et al., 2001; Benavides-Solorio and MacDonald, 2005; Shakesby and Doerr, 2006). Fire severity, as a descriptor of the magnitude of the changes occurred in the soil, has been recognized as a decisive factor controlling those post-fire soil erosion rates (e.g. BenavidesSolorio and MacDonald, 2005; Vega et al., 2005).

Most of these studies have emphasized the reduction or elimination of vegetation cover and ground cover as the main factors explaining the increased soil losses. Soil cover increases infiltration, maintains high soil porosity, prevents

\footnotetext{
* Correspondence to: C. Fernández, Centro de Investigación Forestal de Lourizán, Consellería do Medio Rural, Xunta de Galicia, PO Box 127, 36080 Pontevedra, Spain.

E-mail: cfernandez.cifal@siam-cma.org
}

soil sealing and increases surface roughness, reducing thus soil erosion (De Bano et al., 1998; Larsen et al., 2009). Fire can also alter the soil structure, by affecting bulk density and total porosity, thus reducing infiltration and promoting overland flow (e.g. De Bano et al., 1998; Neary et al., 2005). Fire-induced hydrophobicity (De Bano, 1981; De Bano et al., 1998; Robichaud, 2000; Huffman et al., 2001; Keizer et al., 2008a) may also contribute to increased soil losses. The effect of fire on soil water repellency depends primarily on the amount and type of litter consumed, the duration and amount of soil heating, and the amount of oxygen available during burning (De Bano et al., 1998; Doerr et al., 2009).

Various models already exist that predict soil erosion for a great variety of crop characteristics. Models such as WEPP (Nearing et al., 1989) and EUROSEM (Morgan et al., 1998) can simulate the effects of vegetation on erosion in individual storms, but are often too complex to be used as operational tools. Simpler, empirically based models such as the revised Morgan-Morgan-Finney (MMF) (Morgan, 2001), USLE (Wischmeier and Smith, 1978) or its revised version Revised Universal Soil Loss Equation (RUSLE) (Renard et al., 1997) may be useful for estimating soil erosion on an annual basis (De Roo, 1996; Tiwari et al., 
2000; Morgan, 2001; Morgan and Duzant, 2008). They require less field data than other more complex models and are therefore more feasible as management tools. The USLE model predictions have shown relatively good agreement with other soil erosion estimation data after fire in Galicia (Díaz-Fierros et al., 1987). Acceptable results were also obtained using WEPP and Disturbed WEPP to predict particular soil erosion episodes after fire in Galicia (Soto and Díaz-Fierros, 1998) and the United States (Larsen and MacDonald, 2007). Likewise, the MMF model has performed reasonably well to estimate soil losses in burnt areas in Portugal (Keizer et al., 2008b; Vieira, 2008). However, most of the validation studies of RUSLE and MMF models have been made on agricultural soils (e.g. Shrestha, 1997; Tiwari et al., 2000; Morgan, 2001; Vigiak et al., 2005; López-Vicente et al., 2008; Morgan and Duzant, 2008) and there is a lack of information on the performance of such models in forest soils and, particularly after fire (Dissmeyer and Foster, 1984; Larsen and MacDonald, 2007). Moreover, the validation of soil erosion models after post-fire rehabilitation treatments is particularly scarce all over the world (Robichaud et al., 2007).

Over the last 11 years, there have been about 9000 fires per year in Galicia, representing 47 per cent of forest fires in Spain (Ministerio Medio Ambiente, 2006). Increases in wildfire frequency and burned area are commonly expected under the probable future climate scenarios for the Mediterranean region countries (Moreno, 2005; Carvalho et al., 2008; Good et al., 2008; Moreno, 2009) and also in NW Spain (Vega et al., 2009).

Post-fire soil erosion rates have been assessed in different situations in Galicia, NW Spain (Díaz-Fierros et al., 1987; Vega and Díaz-Fierros, 1987; Díaz-Fierros et al., 1990; Soto et al., 1994; Vega et al., 2005; Fernández et al., 2007, 2008). Operationally useful tools providing reasonable accurate predictions of post-fire sediment yields are needed to guide management decisions to mitigate post-fire soil loss and land degradation and for post-fire rehabilitation planning.
The objective of this study was to assess the performance of the RUSLE and MMF models to predict first-year soil erosion following two wildfires of distinctive severity and after the application of different post-fire rehabilitation treatments in an area affected by a high-severity fire.

\section{MATERIALS AND METHODS}

\section{Study Sites}

The study was carried out in two burned areas with distinct levels of fire severity in Galicia (NW Spain): Verín $\left(41^{\circ}\right.$ $57^{\prime} 10^{\prime \prime} \mathrm{N} ; 7^{\circ} 23^{\prime} 30^{\prime \prime} \mathrm{W} ; 550 \mathrm{~m}$ a.s.l.) and Soutelo $\left(42^{\circ}\right.$ 30 ' $31 " \mathrm{~N} ; 8^{\circ} 17,17 " \mathrm{~W} ; 800 \mathrm{~m}$ a.s.1.). The main characteristics of the areas are summarized in Table I.

\section{Data Collection and Field Measurements}

This study used a set of plots initially installed for quantifying soil erosion after wildfire (Verín) and to assess the effect of different soil rehabilitation treatments on soil erosion (Soutelo).

Fourteen and sixteen experimental plots $\left(50 \times 10 \mathrm{~m}^{2}\right.$ each) with their longest dimension along the maximum slope, were installed in Verín and Soutelo, respectively, just after wildfire and before any appreciable rainfall. The plots were delimited by a geotextile fabric fixed to posts. Uphill borders of the plots were trenched to avoid external inputs from runoff or erosion. Sediment fences, made from a geotextile fabric similar to that described by Robichaud and Brown (2002), were located at the downhill portion of the plots and were used for periodic collection of sediment.

In the Soutelo experimental site to study the effect of different soil rehabilitation treatments on erosion control, three different treatments were assigned at random: straw mulch, wood chip mulch, cut shrub barriers and a control (untreated burned soils). Wheat straw and wood chips were spread manually at a rate of 2.5 and $4 \mathrm{Mg} \mathrm{ha}^{-1}$, respectively. Four barriers made from shrubs cut in an unburned adjacent

Table I. General characteristics of study sites

\begin{tabular}{lcc}
\hline & Verín & Soutelo \\
\hline Location & Ourense province & Pontevedra province \\
Wildfire date & Summer 2003 & Summer 2006 \\
Fire severity & Moderate soil burn severity $=1 \cdot 0$ & Severe soil burn severity $=2 \cdot 7$ \\
Dominant vegetation & Pinus pinaster stand & Ulex europaeus shrubland \\
Climate & Mediterranean & Oceanic \\
Mean air temperature $\left({ }^{\circ} \mathrm{C}\right)$ & 12 & 11 \\
Mean annual precipitation $(\mathrm{mm})$ & 800 & 1500 \\
Mean rainfall erosivity & 1000 & 3000 \\
$\left(\right.$ MJ mm h ${ }^{-1}$ ha $\left.^{-1} \mathrm{y}^{-1}\right)$ & & Alumi-umbric Regosol \\
Soil & Schist & Schist \\
Substrate & & Regosol \\
\hline
\end{tabular}


area were located along the longest dimension of each plot, spaced at regular intervals of $10 \mathrm{~m}$. The barriers were $10 \mathrm{~m}$ long, $0.5 \mathrm{~m}$ wide and $0.7 \mathrm{~m}$ high. Immediately after application of the treatment, the mean soil cover was 80 per cent in the straw mulched plots and 45 per cent in the wood chip mulched plots.

At each study site, amount and intensity of rainfall were measured by two recording rain gauges positioned at $1.20 \mathrm{~m}$ above ground, adjacent to the experimental site.

A few days after the wildfire, the percentage of soil organic cover was visually estimated by use of a $20 \mathrm{~cm} \times 20 \mathrm{~cm}$ quadrat at 20 systematically selected points along two transects parallel to the plot longest dimension in each plot. Reference quadrats, corresponding to $1,5,10$, $15,20,25$ and 50 per cent cover of a $20 \times 20 \mathrm{~cm}^{2}$ quadrat, were prepared on paper to calibrate visual estimates of cover. In addition, each quadrat was assigned to one of the levels of a soil severity index with a modified version of the classification from Ryan and Noste (1983). Four degrees of fire severity were distinguished (Vega et al., 2008): (1) Burnt litter (Oi) but limited duff (Oe + Oa) consumption. (2) Forest floor $(\mathrm{Oi}+\mathrm{Oe}+\mathrm{Oa}$ layers $)$ completely consumed (bare soil) but soil organic matter not consumed and surface soil intact. (3) Forest floor completely consumed and soil organic matter in Ah horizon also consumed, a thick layer of ash deposited and soil structure altered. (4) As (3) and colour altered (reddish). A mean value of these scores was used to assess the impact of fire on soil in each burnt plot.

A few days after fire, the percentage of ground cover by plants established from seeds or resprouting after fire was estimated visually, in a $70 \times 70 \mathrm{~cm}^{2}$ quadrat, at 20 systematically selected points in each plot. Measurements of vegetation height were also made. Sampling was repeated every 3 months in each experimental plot.

Immediately after fire, soil shear strength $(0-5 \mathrm{~cm})$ was measured with a vane tester (Eijkelkamp) at 20 points in each experimental plot. Measurements were made quarterly during the study period.

Samples of surface mineral soil $(0-10 \mathrm{~cm})$ were taken at 15 systematically chosen points within each plot to determine moisture content by gravimetry (oven-dried for $24 \mathrm{~h}$ at $105^{\circ} \mathrm{C}$ ). The samples were taken at monthly intervals during the period of study.

Soil bulk density was determined immediately after fire in both study areas. In Soutelo, the measurements were repeated quarterly. A metal cylinder of $15 \mathrm{~cm}$ diameter was inserted into the upper $5 \mathrm{~cm}$ layer of mineral soil and bulk density was calculated by dividing the oven-dried soil mass by the volume of the soil core (free of gravel).

Soil depth was measured with a metal stick at 20 randomly selected points inside each plot. Further details about the study sites are available in Fernández et al. (2007) and Fernández et al. (in revision).

\section{Application of RUSLE Model}

Application of this model (Renard et al., 1997) was based on the procedure described by Wischmeier and Smith (1978) to estimate soil losses, $A\left(\mathrm{Mgha}^{-1} \mathrm{y}^{-1}\right)$, which consists of the product of five factors, rainfall erosivity, $R\left(\mathrm{MJ} \mathrm{mm} \mathrm{h}^{-1} \mathrm{ha}^{-1} \mathrm{y}^{-1}\right)$, soil erodibility $K$ $\left(\mathrm{Mgh} \mathrm{MJ}^{-1} \mathrm{~mm}^{-1}\right)$, and the non-dimensional topographic factor (LS), crop factor $(C)$ and soil conservation practices factor $(P)$ :

$$
A=R \times K \times L \times S \times C \times P
$$

Determination of the $R$ factor was initially based on rainfall data for all the events that occurred in both study areas during the year of study. The topographic factor was obtained according to the characteristics of the different plots.

The soil erodibility, $K$, was calculated by use of the equation proposed by Wischmeier and Smith (1978) because in both areas the percentage of organic matter was higher than 4 per cent (Renard et al., 1997).

The $C$ factor was calculated according to the following equation:

$$
C=\mathrm{PLU} \times \mathrm{CC} \times \mathrm{SC} \times \mathrm{SR} \times \mathrm{SM}
$$

where PLU is the prior land use subfactor, CC is the canopy cover subfactor, $\mathrm{SC}$ is the surface cover subfactor, $\mathrm{SR}$ is the surface roughness subfactor and SM is the soil moisture subfactor (Renard et al., 1997).

The PLU subfactor is computed from a soil reconsolidation factor, the mass of roots and the mass of buried residue (Renard et al., 1997). A value of 0.45 was assigned to the reconsolidation factor as proposed by Dissmeyer and Foster (1981) for forest soils; the mass of buried residue was assumed to be zero and the mass of roots was obtained according to Achat et al. (2008) for Pinus pinaster and Soto and Díaz-Fierros (1998) for Ulex europaeus.

The CC subfactor was calculated from percent canopy cover and fall height obtained from vegetation surveys in the field.

We used the values proposed by Larsen and MacDonald (2007) to calculate the SC subfactor: a value for the unitless coefficient that indicates the effectiveness of surface cover in reducing erosion (b) of 0.05 as rilling is the dominant process, percent of surface cover (Sp) as the mean of spring and autumn cover in each plot and for roughness of an untilled surface $(\mathrm{Ru})$, a value of $1.52 \mathrm{~cm}$ in the severely burned plots and $2.54 \mathrm{~cm}$ in the moderately severely burned plots. The SR subfactor was calculated using the same Ru values. 
(a)

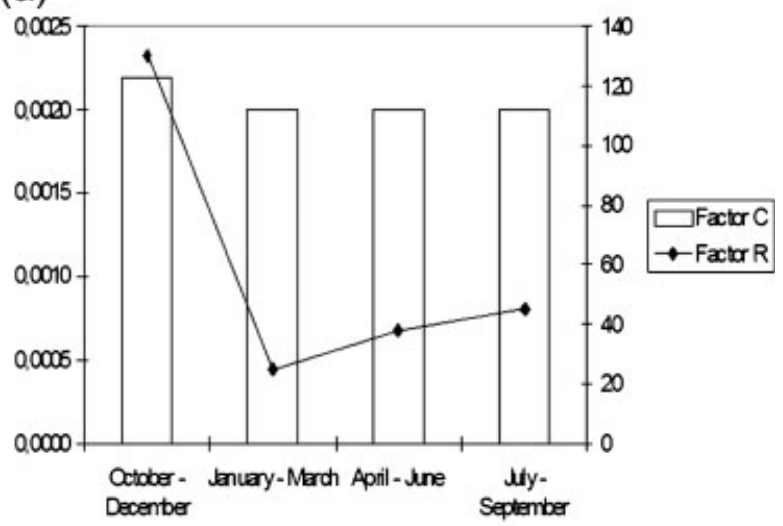

(b)

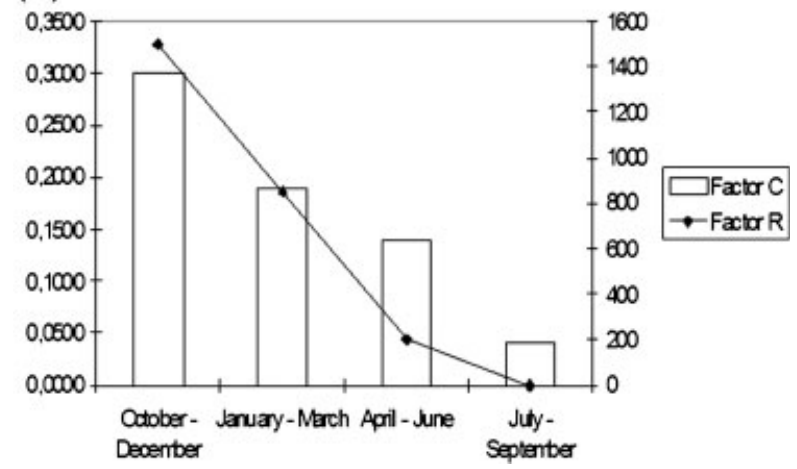

Figure 1. Variation in $R$ and $C$ factors from RUSLE during the period of study in both study areas. (a, Verín; b, Soutelo).

Since the SM subfactor has not been calibrated yet for burned forest soils (González-Bonorino and Osterkamp, 2004), a value of 1.0 was used following Larsen and MacDonald (2007).

Variation in the $C$ and $R$ factors throughout the period of study in both areas is shown in Figure 1. The mean $C$ factor was obtained according to the distribution of rainfall erosivity in each study area.

The maximum value of the $P$ factor was 1 for the plots in which no conservation practices were applied. For the plots in which rehabilitation treatments were carried out, this value changed according to the effectiveness of treatments determined (Fernández et al., in revision) in terms of the ratio between annual soil losses measured in treated and untreated plots ( 0.343 straw mulch; 0.943 wood chip mulch and 0.857 cut shrub barriers).

The input parameters for the RUSLE model are listed in Table II.

\section{Application of Revised Morgan-Morgan-Finney Model (MMF)}

The revised MMF model (Morgan, 2001) used the concepts by Meyer and Wischmeier (1969) and Kirkby (1976). This model separates the soil erosion process in two phases: the water phase and the sediment phase. The water phase determines the energy of rainfall available for soil particles detachment from the soil and the volume of runoff. In the erosion phase, rates of soil particle detachment by rainfall and runoff are determined along with the transport capacity of runoff. Predictions of total particle detachment and transport capacity are compared and erosion rate is equated to the lower of the two rates.

The input parameters in the model are grouped in four factors. The rainfall factor includes annual rainfall $(R)$, rainfall per rainy days $(\mathrm{Rn})$ and the typical value for intensity of erosive rain $(I)$. The soil factor includes, soil moisture at field capacity (MS), bulk density of the top soil layer (BD), hydrological depth of soil (EHD), soil detachability index $(K)$ and cohesion of the surface soil $(\mathrm{COH})$ parameters. The landform factor includes only slope steepness $(S)$. The land cover factor includes rainfall interception $(A)$, actual evapotranspiration (Et), potential evapotraspiration (E0) and crop cover management factor $(C)$, canopy cover (CC), ground cover (GC) and vegetation cover to the ground surface $(\mathrm{PH})$ parameters.

Rainfall parameters $(R, \mathrm{Rn}$ and $I)$ were obtained from the recording rain gauges installed in each study site. The rainfall kinetic energy equations used were those proposed by Coutinho and Tomás (1995) in Verín, and by Marshall and Palmer (1948) in Soutelo.

Soil moisture, bulk density, hydrological depth of soil and cohesion of the surface soil parameters were measured in both areas during the year of study as explained before. The detachability index $(K)$ was obtained according to the soil texture (Morgan, 2001).

Table II. Input parameters for RUSLE model in both study sites

\begin{tabular}{lccc}
\hline Factor & Parameter & Verín Moderate fire & Soutelo Severe fire \\
\hline Rainfall erosivity & $R\left(\mathrm{MJ} \mathrm{mm} \mathrm{h}^{-1} \mathrm{ha}^{-1} \mathrm{y}^{-1}\right)$ & $224(0 \cdot 01)$ & $2547(0 \cdot 02)$ \\
Soil erodibility & $K\left(\mathrm{Mg} \mathrm{ha}^{-1} \mathrm{MJ}^{-1} \mathrm{~mm}^{-1}\right)$ & $0 \cdot 015(0 \cdot 001)$ & $0 \cdot 017(0 \cdot 001)$ \\
Topographic factor & $\mathrm{LS}$ & $6 \cdot 37(0 \cdot 24)$ & $8 \cdot 70(0 \cdot 10)$ \\
Crop factor & $C$ & $0 \cdot 002(0 \cdot 0001)$ & $0 \cdot 249(0 \cdot 001)$ \\
Soil conservation practices & $P$ & 1 & 1
\end{tabular}

Standard errors are given in parentheses. 
Table III. Input parameters for MMF model in both study sites

\begin{tabular}{|c|c|c|c|}
\hline Factor & Parameter & Verín Moderate fire & Soutelo severe fire \\
\hline \multirow[t]{3}{*}{ Rainfall } & $R\left(\mathrm{~mm} \mathrm{y}^{-1}\right)$ & $640 \cdot 4(0 \cdot 2)$ & $1554.9(0.5)$ \\
\hline & $\mathrm{Rn}\left(\mathrm{mm}\right.$ raining day $^{-1}$ ) & $4.5(0 \cdot 2)$ & $15 \cdot 5(0 \cdot 5)$ \\
\hline & $I\left(\mathrm{~mm} \mathrm{~h}^{-1}\right)$ & 18 & 30 \\
\hline \multirow[t]{5}{*}{ Soil } & $\operatorname{MS}(\%)$ & $27(0.02)$ & $25(0 \cdot 01)$ \\
\hline & $\mathrm{BD}\left(\mathrm{g} \mathrm{cm}^{-3}\right)$ & $0.59(0.02)$ & $0.69(0.01)$ \\
\hline & EHD (m) & $0.266(0.02)$ & $0.270(0.03)$ \\
\hline & $K\left(\mathrm{~g} \mathrm{~J}^{-1}\right)$ & $0.5(0.01)$ & $0.5(0.01)$ \\
\hline & $\mathrm{COH}(\mathrm{kPa})$ & $26(0 \cdot 8)$ & $33(2 \cdot 5)$ \\
\hline Landform & $S\left(^{\circ}\right)$ & $16 \cdot 2(0 \cdot 7)$ & $22 \cdot 2(0 \cdot 2)$ \\
\hline \multirow[t]{6}{*}{ Land cover } & A & $0 \cdot 20$ & 0.13 \\
\hline & $\mathrm{Et} / \mathrm{E} 0$ & 0.56 & 0.75 \\
\hline & C & $0.002(0.0001)$ & $0 \cdot 249(0 \cdot 001)$ \\
\hline & $\mathrm{CC}(\%)$ & $34(0 \cdot 5)$ & $0(0 \cdot 0)$ \\
\hline & $\mathrm{GC}(\%)$ & $100(0 \cdot 01)$ & $1(0 \cdot 01)$ \\
\hline & $\mathrm{PH}(\mathrm{m})$ & $13 \cdot 1(0 \cdot 20)$ & $0.6(0.01)$ \\
\hline
\end{tabular}

Standard errors are given in parentheses.

The rainfall interception $(A)$ was computed according to previous studies made in Galicia for pine stands (Gras, 1993) and shrublands (Vega et al., 2005). The potential and actual evapotranspiration were estimated by the methods proposed by Thornthwaite (1948) and Turc (1955), respectively. The $C$ factor of MMF is the product of the $C$ and $P$ factors from the USLE equation (Wischmeier and Smith, 1978), and in the application of this model the same values as obtained from the RUSLE model were applied. Canopy cover (CC), ground cover (GC) and vegetation cover to the ground surface ( $\mathrm{PH})$ parameters were measured in both areas during the year of study as explained before. The model inputs are listed in Table III.

\section{Statistical Analysis}

Predicted annual soil losses values were evaluated by

- Coefficient of efficiency (Nash and Sutcliffe, 1970), Ef, a descriptor of the predictive accuracy of model outputs. Ef can range from $-\infty$ to 1 . A negative value indicates that the mean observed value is a better predictor than the model, a value of 0.0 indicates that the mean observed value is as accurate a predictor as the model and an efficiency of 1 corresponds to a perfect match of predicted to the observed data. The closer the $\mathrm{Ef}$ is to 1, the more accurate the model is.

- The root mean squared errors, RMSE, measures the average magnitude of error between observed and forecasted values.

- The Wilcoxon rank sum method for the difference between forecasted and observed sediment losses. It is a non-parametric test for assessing if two independent samples come from the same distribution.

\section{RESULTS}

\section{Soil Losses after Moderate and Severe Fires}

\section{RUSLE}

The results showed that the model overestimated erosion rates by one order of magnitude, particularly in the severe fire, and whereas the mean measured value of annual soil losses in Soutelo was $3.5 \mathrm{~kg} \mathrm{~m}^{-2}$, those predicted by RUSLE were $9.2 \mathrm{~kg} \mathrm{~m}^{-2}$ (Figure 2). In Verín, the corresponding values were 0.003 and $0.005 \mathrm{~kg} \mathrm{~m}^{-2}$, respectively. The validation statistics for the RUSLE are shown in Table IV. The negative value of the efficiency index indicates that the mean of observed values is a better predictor than the model.

\section{$M M F$}

When the MMF model is applied according to the procedure described by Morgan (2001), all the results depend on the annual transport capacity of runoff. The MMF model tended to underestimate soil erosion rates (Figure 2). The mean predicted value of annual soil losses in Soutelo was $2.6 \mathrm{~kg} \mathrm{~m}^{-2}$ versus $3.5 \mathrm{~kg} \mathrm{~m}^{-2}$ observed and in Verín, $0.0001 \mathrm{~kg} \mathrm{~m}^{-2}$ versus $0.003 \mathrm{~kg} \mathrm{~m}^{-2}$. However, the validation statistics were better than those obtained with the RUSLE model (Table IV) and annual values of predicted and measured soil losses did not differ according to the Wilcoxon test.

\section{Soil Losses after Post-fire Erosion Control Treatments RUSLE}

The application of the RUSLE model to the different treatments applied for erosion control was based on the same inputs that were used for the severe fire in Soutelo (Table II) with the exception of the $P$ factor, which 


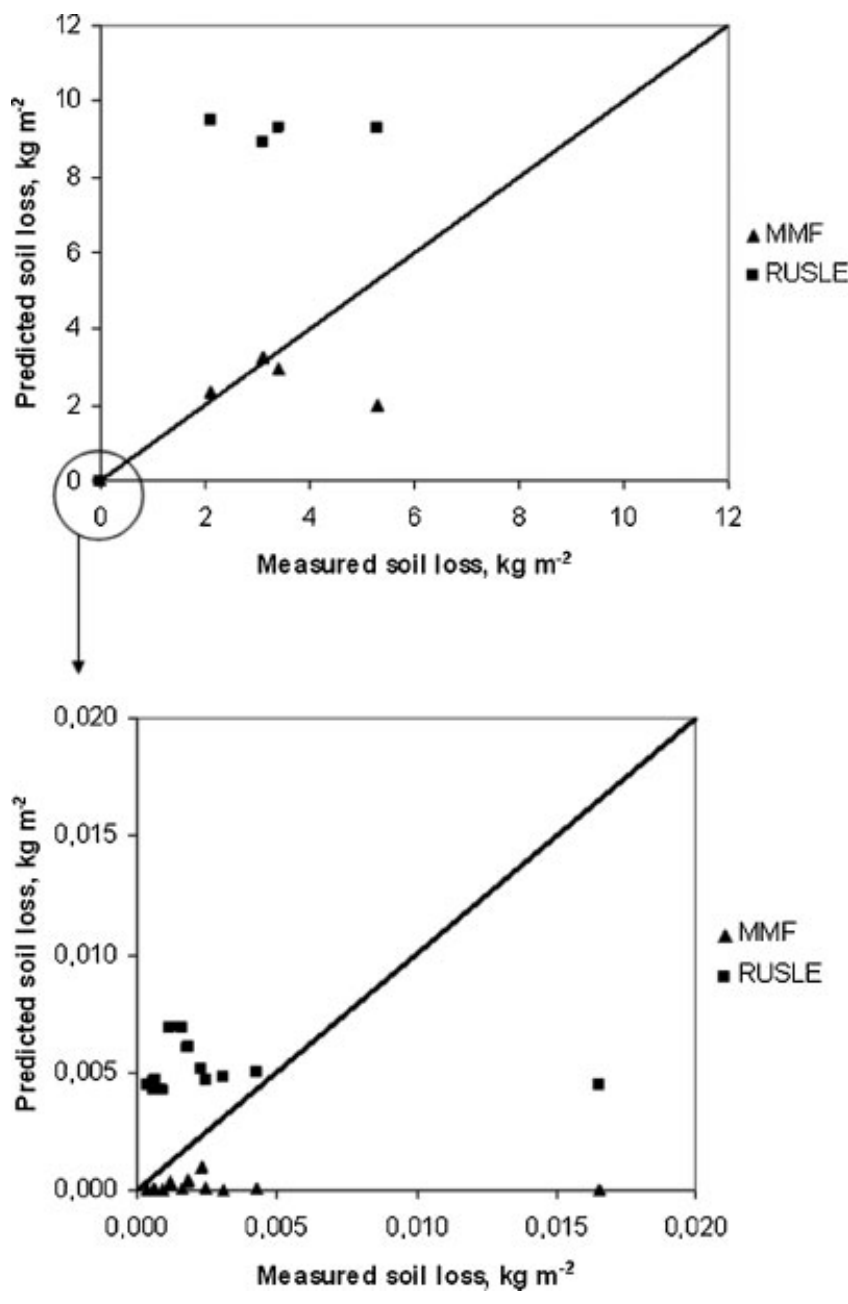

Figure 2. Measured and RUSLE or MMF-predicted soil losses for both study areas.

was different in the treatments: $0 \cdot 343$ for straw mulch, $0 \cdot 857$ for cut shrub barriers and 0.943 for wood chip mulch.

The results showed that the RUSLE model overestimate the soil losses when compared with the measured values (Figure 3). The validation statistics obtained to test the efficacy of RUSLE to predict soil erosion were also very poor (Table V).

Table IV. Validation statistics for the RUSLE and MMF modelling for both study areas

\begin{tabular}{lrr}
\hline & RUSLE & MMF \\
\hline Ef & -2.208 & 0.736 \\
RMSE $\left(\mathrm{kg} \mathrm{m}^{-2}\right)$ & 3.146 & 0.902 \\
Wilcoxon test $-p$-value & 0.000 & 0.913 \\
\hline
\end{tabular}

Copyright (C) 2010 John Wiley \& Sons, Ltd.

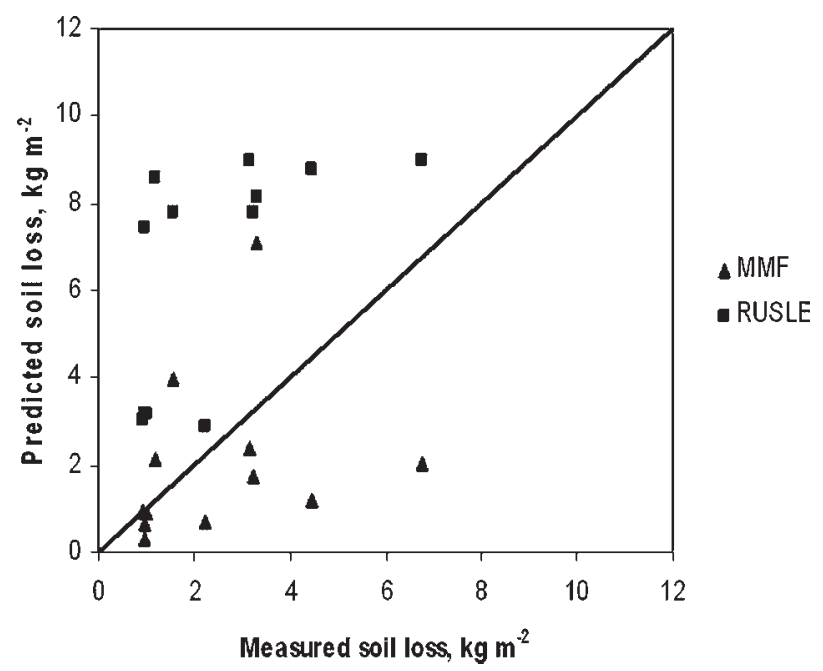

Figure 3. Measured and RUSLE or MMF-predicted soil losses for the treatments applied.

Table V. Validation statistics for the RUSLE and MMF modelling for the treatments applied

\begin{tabular}{lrr}
\hline & RUSLE & \multicolumn{1}{c}{ MMF } \\
\hline Ef & -6.009 & -0.687 \\
RMSE $\left(\mathrm{kg} \mathrm{m}^{-2}\right)$ & 1.914 & 2.457 \\
Wilcoxon test $-p$-value & 0.041 & 0.347 \\
\hline
\end{tabular}

$M M F$

As in RUSLE, the application of the MMF model to the different treatments used for erosion control was based on the same inputs used for the severe fire in the Soutelo site (Table III), with the exception of the $P$ factor, which varied in the different treatments.

The poor agreement between observed and predicted values can be observed in Figure 3. The MMF presented a comparatively better efficiency index that RUSLE (Table V). No differences between predicted and observed valves of soil losses were found (Table V).

\section{DISCUSSION}

The reasonably good predictions of post-fire soil losses achieved with MMF is consistent with those previously observed in burned areas in Portugal (Keizer et al., 2008b; Vieira, 2008). The poorer results obtained with RUSLE are similar to those reported by Larsen and MacDonald (2007), who also observed negative efficiency indexes when predicting sediment yields the first year after fires of different levels of fire severity in Colorado (USA) with RUSLE. Better results were obtained by Díaz-Fierros et al. 
(1987) with the application of USLE, although the different methodology used to measure soil losses in the field do not allow direct comparison with data obtained in the present study. Soto and Díaz-Fierros (1998) obtained efficiency indexes of 0.6 and 0.03 after prescribed burning and wildfire, respectively, in shrublands in NW Spain, with the WEPP model.

The results presented here correspond to the first year after fire and this may limit the accuracy of the predictions as it has been shown that models are better for predicting average conditions than soil losses for particular years (Larsen and MacDonald, 2007).

There is no data available from rehabilitation studies of burned areas for comparing the accuracy of prediction achieved by the models in the plots to which rehabilitation treatments were applied.

Although there is a considerable number of studies testing RUSLE, the available information on burned soils is particularly scarce. The overestimation of soil losses predicted by RUSLE, particularly in the severe fire, contrasts with the findings of Larsen and MacDonald (2007).

One of the possible reasons for the overestimates may be the use of an inadequate kinetic energy equation of rainfall for this climate, although its original formulation seems to be appropriate under oceanic influence climates (Van Dijk et al., 2002). Larsen and MacDonald (2007) suggest the incorporation of a rainfall erosivity threshold and a nonlinear relationship between rainfall erosivity and soil losses to improve the ability of RUSLE to predict post-fire soil erosion. However, in their case, convective storms were the dominant type of rainfall events.

In the present study, an alternative estimation of $R$ according to the formulation proposed by Roose (1975) and Morgan (1995) for tropical areas, which involves multiplying the annual rainfall by 0.865 , would result in a lower $R$ value and increased the efficiency index from $-2 \cdot 208$ (Table IV) to 0.690 and the RMSE decreased to $0.977 \mathrm{~kg} \mathrm{~m}^{-2}$. This suggests that $R$ calculated by the Wischmeier and Smith (1978) equation would overestimate the rainfall erosivity effect in this area.

The primary effects of burning are to alter the soil and surface cover, so this may induce noticeable changes in the $K$ and $C$ factors. The model estimations suggest that the $K$ and $C$ factors do not adequately describe soil modifications after fire.

The $K$ factor is based on soil texture, soil organic matter, permeability class and soil structure. The decline in infiltration caused by increased post-fire soil water repellency is often considered as the primary cause of the increase in runoff after burning (e.g. DeBano, 2000; Shakesby and Doerr, 2006), although soil water repellency is not explicitly considered in the RUSLE model and was not measured in this study. Miller et al. (2003) suggested changing the permeability class chosen in the initial calculations to very slow, to take into account the effect of post-fire soil water repellency in the $K$ factor. Moreover, very severe fires may also reduce the structural stability of the soil and increase the soil erodibility (Soto et al., 1991; Cerdá et al., 1995; Andreu et al., 2001; García-Corona et al., 2004; Mataix-Solera and Doerr, 2004). However, the opposite relationship is assumed in the quantitative effect of the structure classes on the $K$ factor. As a result, a decrease in aggregate stability after fire decreases rather than increases the $K$ factor. Larsen and MacDonald (2007) suggest that the current algorithms for calculating $K$ values are not consistent with the understanding of erosion processes after fire and propose that a reformulation would be required to achieve more precise predictions. However, in the present case, the proposed modifications would produce an increase in the RUSLE predictions. The influence of the reduction of the soil organic matter content on soil erodibility after fire is not clear in these soils, because of the observed high content even after very severe fire and may partially explain the overestimation observed in the present study.

The cover-management factor $(C)$ is one of the most important variables because soil organic cover is a major determining factor as regards post-fire sediment yields (e.g. Pierson et al., 2001; Pannkuk and Robichaud, 2003; Benavides-Solorio and MacDonald, 2005; Vega et al., 2005, Wagenbrenner et al., 2006; Fernández et al., 2007, 2008). The values of $C$ obtained here appear to contribute to an overestimation of soil erosion losses in the high-severity area. The problem is that data on soil consolidation over time, soil root mass over time, drop fall height and surface roughness are approximations, because of the absence of detailed field data for an accurate calculation of this factor. In the absence of such data, it is not possible to assess the validity of the relationships used to calculate the $C$ factor (González-Bonorino and Osterkamp, 2004; Larsen and MacDonald, 2007).

As stated before with the $K$ factor, the high soil organic matter content of these soils could affect the computation of the $C$ factor. Dissmeyer and Foster (1981) proposed a correction in the $C$ factor for soils with high soil organic matter content that consists in multiplying the previously computed value of $C$ by 0.7 . If we use this correction factor, the $C$ values would be 0.002 and 0.17 for the moderately and severely burned areas, respectively. Taking into account the above modifications in the $C$ and $R$ factors (Figure 4), the efficiency index increased to 0.872 and the RMSE decreased to $0.628 \mathrm{~kg} \mathrm{~m}^{-2}$.

Unexpectedly, although the MMF model was not developed for burned soils, the Ef index obtained suggests the suitability of this model for predicting soil erosion after a fire. The discrepancies between observed and predicted data 

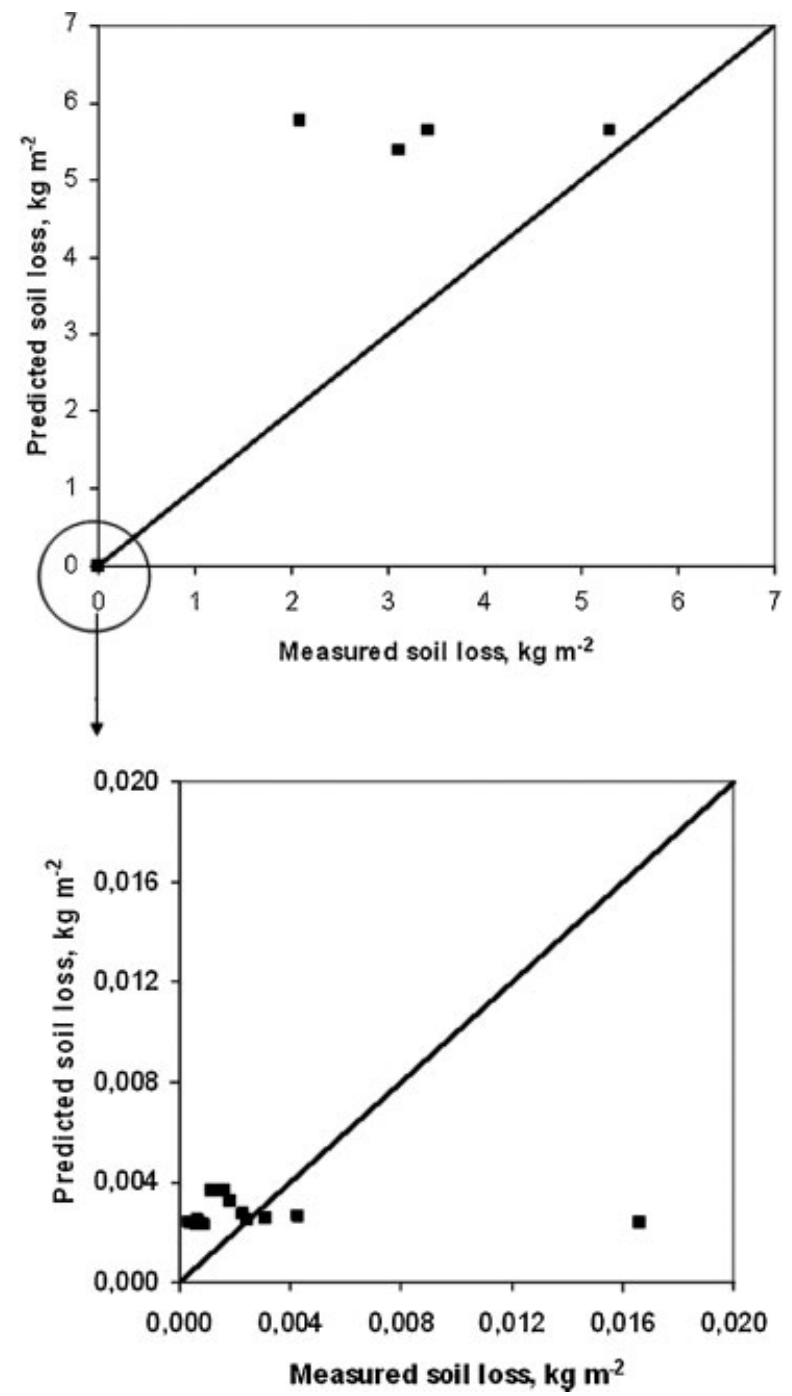

Figure 4. Measured and RUSLE-predicted soil losses for both study areas after the modification of the $R$ and $C$ factors.

may be related to the fact that estimated values of evapotranspiration were used and there was no vegetative cover during some months. It is uncertain how these estimations could affect the soil moisture storage capacity in these burned soils and, thus the model predictions.

As stated by Morgan (2001), the hydrological depth of soil is a controversial parameter, and although in the present case the values used were based on field measurements, there remain uncertainties as regards the real value. Better knowledge of these parameters would probably produce more accurate estimations of soil erosion.

As regards as soil losses after post-fire erosion control treatments predictions, there are several possible reasons for the poor results obtained. For example, the values assigned to the $P$ factor. As pointed out by Miller et al. (2003), $P$ factor values are usually unreliable because of the lack of validation of the effectiveness of post-fire rehabilitation treatments. However, in the present study, we chose the values according to the respective efficacy values for the soil rehabilitation treatments measured in a field experiment (Fernández et al., in revision). The value of $P$ for cut shrub barriers is consistent with that proposed by Miller et al. (2003) and with the results of some field studies on the effectiveness of rehabilitation treatments after fire (Wagenbrenner et al., 2006; Robichaud et al., 2008). A reduction in factor LS, taking into account the distance between barriers along the slope did not improve predictions.

The proposed modifications of $R$ and $C$ factors in the RUSLE substantially improved the predictions $(\mathrm{Ef}=0.333)$.

\section{CONCLUSIONS}

Post-fire soil losses predicted by the RUSLE and MorganFinney models were compared in two burned areas with different levels of fire severity in NW Spain. An acceptable efficiency index was only obtained with the MMF model although it slightly underestimates post-fire soil losses.

RUSLE model predictions overestimated actual annual soil losses. RUSLE $K$ factor did not allow to reflect the changes on soil permeability and structure after fire. A correction of $C$ factor to take into account the high organic matter content of the studied soils and a modification of the $\mathrm{R}$ factor could improve the applicability of RUSLE on similar burned soils as those under study.

The differences between observed and predicted values with MMF may be caused by using estimated values for evapotranspiration and how they affect the soil moisture storage capacity. More research on this aspect is needed.

No accurate prediction of soil erosion after soil rehabilitation was achieved with the models tested. The role played by the $C$ and $P$ factors was not fully established and may have led to the poor results.

Despite their limitations, both models were able to clearly distinguish situations of high and low post-fire erosion risk. This shows the applicability of both models to be used as operational tools in terms of prioritizing management areas.

\section{ACKNOWLEDGEMENTS}

This study was funded by the National Institute of Agricultural Research of Spain (INIA) through projects RTA-03-205-C2-2 and RTA2007-00111-C02-01. We are grateful to all those who helped with field work and laboratory analyses, particularly Antonio Arellano, José R. González, Isidro Cruz, Jesús Pardo, Francisco Javier Gallego, Francisco Mella, Elena Pérez, Belén González, 
Mario López, María Ventosinos, Angela López and Dolores Vázquez. We sincerely acknowledge the critical reviews of two anonymous referees who helped improve an early version of the manuscript.

\section{REFERENCES}

Achat DL, Bakker MR, Trichet P. 2008. Rooting patterns and fine root biomass of Pinus pinaster assessed by trench wall and core methods. Journal of Forest Research 13: 165-175.

Andreu V, Imeson AC, Rubio JL. 2001. Temporal changes in soil aggregates and water erosion after a wildfire in a Mediterranean pine forest. Catena 44: 69-84.

Benavides-Solorio J, MacDonald LH. 2005. Measurement and prediction of post-fire erosion at hillslope scale, Colorado Front Range. International Journal of Wildland Fire 14: 457-474.

Campbell RE, Baker MB, Ffolliot PF, Larson FR, Avery CC. 1977. Wildfire effects on a ponderosa pine ecosystem: An Arizona case study. USDA Forest Service. Rocky Mountain Forest and Range Experiment Station Research Paper. RM 191.

Carvalho A, Flannigan M, Logan K, Miranda A, Borrego C. 2008. Fire activity in Portugal and its relationship to weather and the Canadian Fire Weather Index System. International Journal of Wildland Fire 17: 328338.

Cerdá A, Imeson AC, Calvo A. 1995. Fire and aspect induced differences on soil erodibility and hydrology of soils at La Costera, Valencia, Southeast Spain. Catena 24: 289-304.

Coutinho MA, Tomás P. 1995. Characterisation of raindrop size distributions at the Vale Formoso Experimental Erosion Centre. Catena 25: 187-197.

De Bano LF. 1981. Water repellent soils: A state of art. USDA Forest Service General Technical Report, PSW-46.

DeBano LF. 2000. The role of fire and soil heating on water repellency in wildland environments: A review. Journal of Hydrology 231-232: 195206.

De Bano LF, Neary DG, Ffolliott PF. 1998. Fire's Effects on Ecosystems. John Wiley and Sons: New York.

De Roo APJ. 1996. Validation problems of hydrologic and soil-erosion catchment models: Examples from a Dutch soil erosion project. In Advances in Hillslope Processes, Anderson MG, Brooks SM (eds). Wiley: Chichester; 669-683.

Díaz-Fierros F, Benito E, Pérez R. 1987. Evaluation of the U.S.L.E. for prediction of erosion in burnt forest areas in Galicia (NW Spain). Catena 14: $189-199$.

Díaz-Fierros F, Benito E, Vega JA, Castelao A, Soto B, Pérez R, Taboada T. 1990. Solute loss and soil erosion in burnt soils from Galicia (NW Spain). In Fire and Ecosystem Dynamics, Goldammer JG, Jenkins y MJ (eds). SPB Academic Publishing: The Hague; 103-116.

Dissmeyer GE, Foster GR. 1981. Estimating the cover management factor in the USLE for forest conditions. Journal of Soil Water Conservation 36: 235-240.

Dissmeyer GE, Foster GR. 1984. A guide for predicting sheet and rill erosion on forest land, Technical Publication R8-TP 6.

Doerr SH, Shakesby RA, MacDonald LH. 2009. Soil water repellency: A key factor in post-fire erosion. In Restoration Strategies after Forest Fires, Cerdá A, Robichaud P R (eds). Science Publishers, Inc.: Enfield, NH.

Fernández C, Vega JA, Fonturbel MT, Jiménez E, Pérez JR. 2008. Immediate effects of prescribed burning, chopping and clearing on runoff, infiltration and erosion in a shrubland area in Galicia (NW Spain). Land Degradation and Development 19: 502-515.

Fernández C, Vega JA, Fonturbel MT, Pérez-Gorostiaga P, Jiménez E, Madrigal J. 2007. Effects of wildfire, salvage logging and slash treatments on soil degradation. Land Degradation and Development 18: 591607.

Fernández C, Vega JA, Jiménez E, Fonturbel MT (in revision). Effectiveness of different post-fire erosion control treatments in Galicia (NW Spain). International Journal of Wildland Fire.
García-Corona R, Benito E, de Blas E, Varela ME. 2004. Effects of heating on some soil physical properties related to its hydrological behaviour in two north-western Spanish soils. International Journal of Wildland Fire 13: $195-199$.

González-Bonorino G, Osterkamp WR. 2004. Applying RUSLE 2.0 on burned forest lands: An appraisal. Journal of Soil and Water Conservation 59: $36-42$.

Good P, Moriondo M, Giannakopoulos C, Bindi M. 2008. The meteorological conditions associated with extreme fire risk in Italy and Greece: Relevance to climate model studies. International Journal of Wildland Fire 17: 155-165.

Gras JM. 1993. Investigación sobre las relaciones hídricas de las plantaciones de E. globulus en Galicia. PhD. Dissertation, Universidad Politécnica de Madrid.

Huffman EL, MacDonald LH, Stednick JD. 2001. Strength and persistence of fire-induced soil hydrophobicity under ponderosa and lodgepole pine, Colorado Front Range. Hydrological Processes 15: 2877-2892.

Johansen MP, Hakonson TE, Breshears DD. 2001. Post-fire runoff and erosion from rainfall simulation: Contrasting forests with shrublands and grasslands. Hydrological Processes 15: 2953-2965.

Keizer JJ, Doerr SH, Malvar MC, Prats SA, Ferreira RSV, Oñate MG, Coelho COA, Ferreira AJD. 2008a. Temporal variation in topsoil water repellency in two recently burnt eucalypt stands in north-central Portugal. Catena 74: 192-204.

Keizer JJ, Nunes JP, Palacios E, Beekman W, Malvar MC. 2008b. Soil erosion modeling for two recently burnt eucalypt slopes: Comparing MEFIDIS, MMF and USLE. ISCO2008, 15th Conference of the International Soil Conservation Organization, Budapest, Hungary, 18-23 May.

Kirkby MJ. 1976. Hydrological slope models: The influence of climate. In Geomorphology and Climate, Derbyshire E (ed.). Wiley: London; 247267.

Larsen IJ, MacDonald LH. 2007. Predicting post-fire sediment yields at the hillslope scale: Testing RUSLE and Disturbed WEPP. Water Resources Research 43: W11412.

Larsen IJ, MacDonald LH, Brown E, Rough D, Welsh MJ, Pietraszek JH, Libohova Z, Benavides-Solorio J, Schaffrath K. 2009. Causes of post-fire runoff and erosion: Water repellency, cover, or soil sealing? Soil Science Society American Journal 73: 1393-1407.

López-Vicente M, Navas A, Machín J. 2008. Modelling soil detachment rates in rainfed agrosystems in the south-central Pyrenees. Agricultural Water Management 95: 1079-1089.

Marshall JS, Palmer WM. 1948. Relation of rain drop size to intensity. Journal of Meteorology 5: 165-166.

Martin D, Moody JA. 2001. Comparison of soil infiltration rates in burned and unburned mountainous watersheds. Hydrological Processes 15: 2893-2903.

Mataix-Solera J, Doerr SH. 2004. Hydrophobicity and aggregate stability in calcareous topsoils from fire-affected pine forests in southeastern Spain. Geoderma 118: 77-88.

Megahan WF, Molitor AC. 1975. Erosional effects of wildfire and logging in Idaho. Water Management Symposium. Logan, UT; 423-444.

Meyer LD, Wischmeier WH. 1969. Mathematical simulation of the process of soil erosion by water. Transactions of the America Society of Agricultural Engineers 12: 754-758 and 762.

Meyer GA, Pierce JL, Wood SH, Jull AJT. 2001. Fire, storms, and erosional events in the Idaho Batholith. Hydrological Processes 15: 30253038.

Miller JD, Nyhan JW, Yool SR. 2003. Modeling potential erosion due to the Cerro Grande fire with a GIS-based implementation of the Revised Universal Soil Loss Equation. International Journal of Wildland Fire 12: $85-100$.

Ministerio de Medio Ambiente. 2006. Los incendios forestales en España: Decenio 1996-2005. Madrid.

Moreno JM. 2005. Impacto sobre los riesgos naturales de origen climático. Riesgo de incendios forestales. In Moreno JM (coord.), Evaluación preliminar de los impactos en España por efecto del cambio climático. Ministerio de Medio Ambiente (Madrid); 1-64.

Moreno JM. 2009. Impacts on potential wildfire risk due to changes in climate. In Birot Y (ed.). Living with Wildfires: What Science Can Tell 
Us. A Contribution to the Science-Policy Dialogue, EFI Discussion Paper 15; European Forest Institute. Joensuu.

Morgan RPC. 1995. Soil Erosion and Conservation, 2nd edn. Longman Group Limited, London.

Morgan RPC. 2001. A simple approach to soil loss prediction: A revised Morgan-Morgan-Finney model. Catena 44: 305-322.

Morgan RPC, Quinton JN, Smith RE, Govers G, Poesen JWA, Auerswald K, Chisci G, Torri D, Styzcen ME. 1998. The European Soil Erosion Model (EUROSEM): A dynamic approach for predicting sediment transport from fields and small catchments. Earth Surface Processes and Landforms 23: 527-544.

Morgan RPC, Duzant JH. 2008. Modified MMF (Morgan-Morgan-Finney) model for evaluating effects of crops and vegetation cover on soil erosion. Earth Surface Processes and Landforms 32: 90-106.

Nash JE, Sutcliffe JV. 1970. River flow forecasting through conceptual models. Part 1: A discussion of principles. Journal of Hydrology 10: 282 290.

Nearing MA, Foster GR, Lane LJ, Finkner SC. 1989. A process-based soil erosion model for USDA-water erosion prediction project technology. American Society of Agricultural Engineers 32: 1587-1593.

Neary DG, Ryan KC, De Bano LF. 2005. Wildland fire in ecosystems. Effects of fire on soil and water. General Technical Report. RMRS-GTR42-vol 4. USDA Forest Service, Rocky Mountain Research Station: Ogden, UT.

Pannuk CD, Robichaud PR. 2003. Effectiveness of needle cast at reducing erosion after forest fires. Water Resources Research 39: 1333-1342.

Pierson FB, Robichaud PR, Spaeth KE. 2001. Spatial and temporal effects of wildfire on the hydrology of a steep rangeland watershed. Hydrological Processes 15: 2953-2965.

Renard KG, Foster GR, Weesies GA, Mc Cool DK, Yoder DC. (coordinators). 1997. Predicting soil erosion by water: A guide to conservation planning with the revised universal soil loss equation (RUSLE). Agriculture Handbook $n^{\circ}$ 703. USDA, Natural Resources Conservation Service: Washington, DC.

Robichaud PR. 2000. Fire effects on infiltration rates after prescribed fire in Northern Rocky Mountain forests, USA. Journal of Hydrology 231-232: 220-229.

Robichaud PR, Brown RE. 2000. What happened after the smoke cleared: Onsite erosion rates after a wildfire in eastern Oregon. In Proceedings Wildland Hydrology Conference 1999, Olsen DS, Potyondy JP (eds). American Resources Association: Hernon, VA; 419-426.

Robichaud PR, Brown RE. 2002. Silt fences: An economical technique for measuring hillslope soil erosion. General Technical Report RMRS-GTR94, USDA Forest Service.

Robichaud PR, Elliot WJ, Pierson FB, Hall DE, Moffet CA. 2007. Predicting postfire erosion and mitigation effectiveness with a web-based probabilistic erosion model. Catena 71: 229-241.

Robichaud PR, Pierson FB, Brown RE, Wagenbrenner JW. 2008. Measuring effectiveness of three postfire hillslope erosion barrier treatments, western Montana, USA. Hydrological Processes 22: 159-170.

Roose EJ. 1975. Erosion et ruissellement en Afrique de l'ouest: vingt années de mesures en petites parcelles experimentales. Cyclo. ORSTOM: Adiopodoumé, Ivory Coast.

Ryan KC, Noste NV. 1983. Evaluating prescribed fires. In Lotan JE, Kilgore BM, Fischer WC, Mutch RW (Tech. Coord.), Symposium and Workshop of Wilderness Fire. Proc. General Technical Report. INT-182, USDA Forest Service Res. Sta.; 230-238.

San Roque P, Rubio JL, Mansanet J. 1985. Efectos de los incendios forestales en las propiedades del suelo, en la composición florística y en la erosión hídrica de zonas forestales de Valencia (España). Revue d'Ecologie et Biologie du Sol 22: 131-147.

Scott DF, Versfeld DB, Lesch W. 1998. Erosion and sediment yield in relation to afforestation and fire in the mountains of the Western Cape Province, South Africa. South African Geographical Journal 80: $52-59$.

Shakesby RA, Coelho COA, Ferreira AD, Terry JP, Walsh RPD. 1993. Wildfire impacts on soil erosion and hydrology in wet Mediterranean forest, Portugal. International Journal of Wildland Fire 3: 95-110.

Shakesby RA, Doerr SH. 2006. Wildfire as a hydrological and geomorphological agent. Earth-Science Reviews 74: 269-307.

Shrestha DP. 1997. Assessment of soil erosion in the Nepalese Himalaya: A case study in Likhu Khola Valley, Middle Mountain Region. Land Husbandry 2: 59-80.

Soto B, Basanta R, Benito E, Pérez R, Díaz-Fierros F. 1994. Runoff and erosion from burnt soils in Northwest Spain. In Soil Erosion as a Consequence of Forest Fires, Sala M, Rubio JL (eds). Geoforma: Logroño, Spain; 91-98.

Soto B, Benito E, Díaz-Fierros F. 1991. Heat-induced degradation processes in forest soils. International Journal of Wildland Fire 1: $147-152$.

Soto B, Díaz-Fierros F. 1998. Runoff and soil erosion from areas of burnt scrub: Comparison of experimental results with those predicted by the WEPP model. Catena 31: 257-270.

Thornthwaite CW. 1948. An approach toward a rational classification of climate. Geographical Review 38: 55-94.

Tiwari AK, Risse LM, Nearing MA. 2000. Evaluation of WEPP and its comparison with USLE and RUSLE. Transactions of the American Society of Agricultural Engineers 43: 1129-1135.

Turc L. 1955. Le bilan d' eau des sols. Relations entre les precipitations, l' evaporation, et l' ecoulement. Annales Agronomiques 6: 5-131.

Van Dijk AIJM, Bruijnzeel LA, Rosewell CJ. 2002. Rainfall intensitykinetic energy relationships: A critical literature appraisal. Journal of Hydrology 261: 1-23.

Vega JA, Díaz-Fierros F. 1987. Wildfire effects on soil erosion. Ecologia Mediterranea 13: 175-181.

Vega JA, Fernández C, Fonturbel T. 2005. Throughfall, runoff and soil erosion alter prescribed burning in gorse shrubland in Galicia (NW Spain). Land Degradation \& Development 15: 1-15.

Vega JA, Fernández C, Jiménez E, Ruiz AD. 2009. Evidencias de cambio climático en Galicia a través de la tendencia de los índices de peligro de incendios forestales. In Evidencias e impactos del cambio climático en Galicia. Xunta de Galicia, Santiago de Compostela; 173-194.

Vega JA, Fernández C, Pérez-Gorostiaga P, Fonturbel MT. 2008. The influence of fire severity, serotiny, and post-fire management on Pinus pinaster Ait. recruitment in three burnt areas in Galicia (NW Spain). Forest Ecology and Management 256: 1596-1603.

Vieira DCS. 2008. Cartografia de risco de erosão, à escala de encosta, numa área recentemente ardida na região Centro. M.Sc. Thesis, University of Aveiro: Portugal.

Vigiak O, Okoba BO, Sterk G, Groenenberg S. 2005. Modelling catchmentscale erosion patterns in the East African Highlands. Earth Surface Processes and Landforms 30: 183-196.

Wagenbrenner JW, Mac Donald LH, Rough D. 2006. Effectiveness of three post-fire rehabilitation treatments in the Colorado Front Range. Hydrological Processes 20: 2989-3006.

Wischmeier WH, Smith DD. 1978. Predicting rainfall-erosion losses- a guide to conservation planning. Agriculture Handbook $N^{\circ} 537$. USDA: Washington, DC; 58. 